\title{
The Chinese Health Care System
}

\section{Structure, Problems and Challenges}

Hougaard, Jens Leth; Østerdal, Lars Peter; Yu, Yi

Publication date:

2008

Document version

Publisher's PDF, also known as Version of record

Citation for published version (APA):

Hougaard, J. L., Østerdal, L. P., \& Yu, Y. (2008). The Chinese Health Care System: Structure, Problems and Challenges. Department of Economics, University of Copenhagen. 


\title{
Discussion Papers Department of Economics University of Copenhagen
}

\author{
No. $08-01$
}

The Chinese Health Care System: Structure, Problems and Challenges

Jens Leth Hougaard, Lars Peter Østerdal and Yi Yu

Studiestræde 6, DK-1455 Copenhagen K., Denmark

Tel. : +4535323082 - Fax: +4535323000

http://www.econ.ku.dk

ISSN: 1601-2461 (online) 


\title{
The Chinese Health Care System: Structure, Problems and Challenges
}

\author{
By \\ Jens Leth Hougaard, Lars Peter Østerdal and Yi Yu \\ Department of Economics \\ University of Copenhagen
}

January 2008

\begin{abstract}
In the present paper we describe the structure of the Chinese health care system and sketch its future development. We analyse issues of provider incentives and the actual burden sharing between government, enterprises and people. We further aim to identify a number of current problems and link these to a discussion of future challenges in the form of an aging population, increased privatization and increased inequity.
\end{abstract}

JEL codes: H51, H75, I11, I18.

Key words: Chinese health care system, provider incentives, burden sharing, aging population, inequity.

Corresponding author: Jens Leth Hougaard, Department of Economics, University of Copenhagen, Studiestraede 6, DK-1455, Copenhagen K. E-mail:

jens.leth.hougaard@econ.ku.dk 


\section{Introduction}

In the late 80ies the Chinese government launched a major reform of the social insurance system, including reforms of pension- and health care schemes. This reform has had a huge impact on the organization of the entire public welfare system. It has been implemented using a series of local experiments, of which particular models have been selected for national implementation. The system is constantly changing trying to respond to current financial problems and adapt to the need of the population.

Despite many efforts, the general impression of the population as well as the governing authorities is that the reform has not been successful. ${ }^{1}$ Cost inflation has been difficult to control and the huge inequality in access seems to be further increased. On top of this, the reform process itself has made the population confused and uncertain about their rights in the system and when adding that the lack of regulation makes the system more exposed to corruption this distrust only becomes worse.

China is a country with huge regional differences. It is therefore questionable whether it makes sense to talk about one coherent system or whether one should more likely consider the system as several co-exiting subsystems - subsystems that seem to be related to different groups of people as well as differences in geographic location. Moreover, any empirical analysis of the Chinese health care system will suffer from considerable data uncertainties and often even a crucial lack of relevant data.

Nevertheless, there have been many previous papers aiming to describe the Chinese health care system and its reforms, e.g. Hsiao (1995), Yip and Hsiao (1997), Hu et al. (1999), $\mathrm{Hu}$ (2004), Blumenthal and Hsiao (2005) and the recent survey by Eggleston et al. (2007). The present paper follows up on these works describing and analyzing the present structure and organization of the Chinese health care system. We try to identify the root of the main problems with the current system, and discuss these in relation to the immense

\footnotetext{
${ }^{1}$ See e.g. Development Research Center of the State Council \& WHO (2005).
} 
future challenges of the system such as an aging population, increasing privatization and greater inequalities.

We focus in particular on the burden sharing and provider incentives. Concerning the burden sharing issue we find that the actual level of risk sharing is relatively low and in reality people are left to cover the main part of their health care expenses by themselves, which again creates huge inequalities in access to health care among the population. Moreover, provider incentives seem to intensify this problem by creating substantial cost inflation.

The paper is organized as follows: Section 2 is a general description of the Chinese health care system: The overall organization, the financing, the allocation of health care benefits, and a description of the providers including their incentives. Section 3 summarises the main problems exposed during the analysis in Section 2, and finally Section 4 concludes with some considerations on future challenges of the Chinese health care system.

\section{The Chinese Health Care System}

In connection with China's economic reforms in the early 80ies the health care system went from an old style communist system with the central government as owner, sponsor and provider to a system where the central government plays a much more limited role. The responsibility for financing and administering the health care sector was mainly transferred to the local authorities of the different provinces. Financing the services therefore became dependent upon local taxation paving the way for substantial inequalities between rich costal regions and poor rural regions. By reducing the public financial support, the providers in the health care sector were also forced (and allowed) to earn profits on specific types of treatments and drug sales introducing various moral hazard issues, which, much like in the U.S., resulted in a significant cost inflation and further inequality in access, see e.g. Blumenthal and Hsiao (2005) . 
The current health care system, which is the result of a series of health care reforms and local experiments in the 90ies can be characterized by an overall structure as illustrated in the flowchart of Figure 2.1 below.

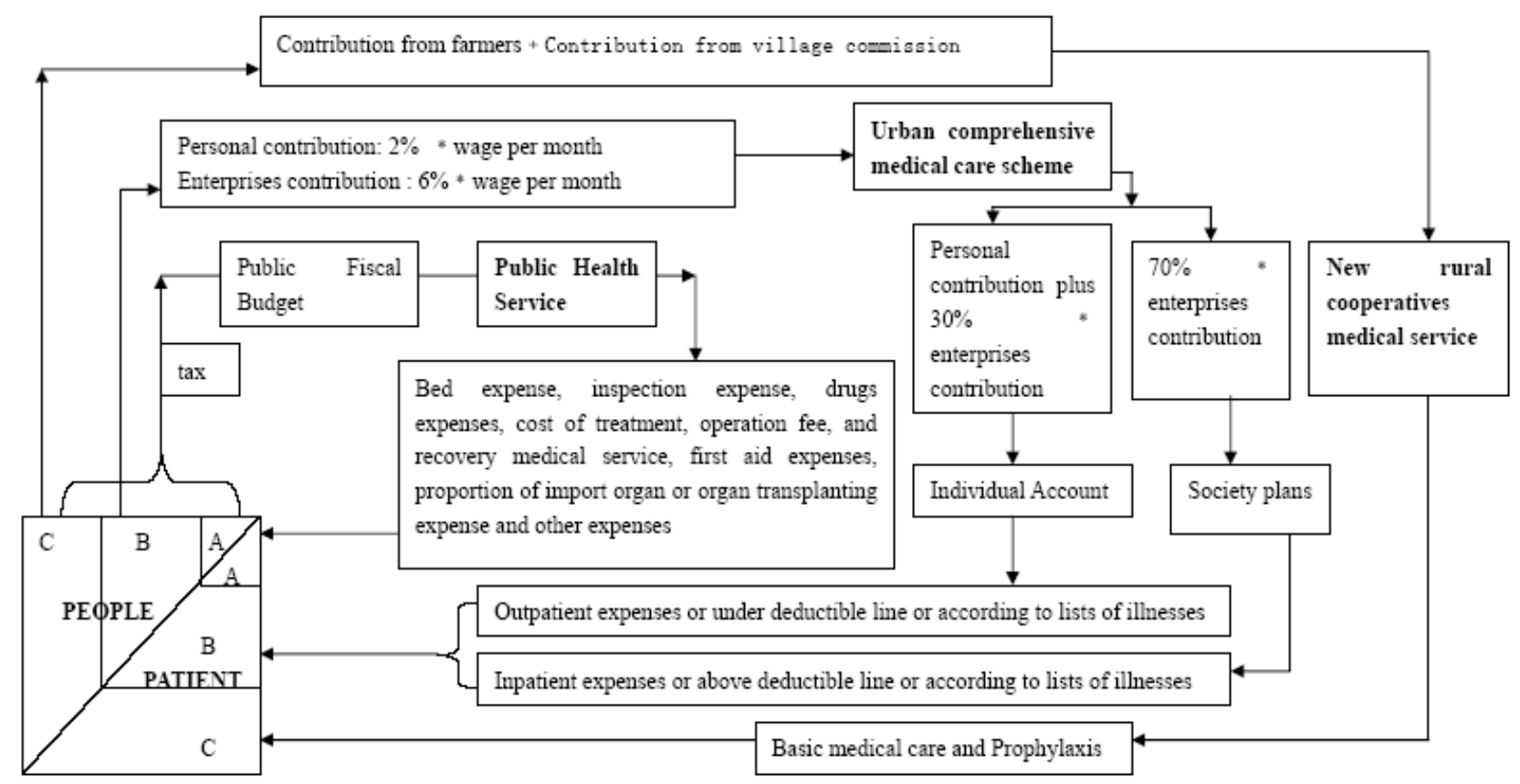

Figure 2.1: The Chinese health care system

Basically, the system design builds on a separation of the population into three groups called A, B and C according to job functions. The A-group consists of staff in all levels of government, the "parties", NGO-like groups, public organizations, the army, staff in the public health sector and research institutions as well as in the education system (including university students). This group is regulated by the "public health service administration act" from 1988. The B-group consists of staff in all kinds of enterprises in urban areas (regulated by "the decision of the state council about construction of comprehensive medical care scheme among urban workers" from 1998) while the C-group consists of population in rural areas not covered by any specific regulation. A very small subset of 
those in the C-group is under "new rural cooperative medical care scheme" - typically farmers located around the south east part of the costal area.

There is no official statistic that accounts for the relative sizes of the three groups A, B and C, but a rough estimate (based on the estimate of Central Party University, reports from the Labour and Social Security Ministry, and the National Bureau of Statistic of China) ${ }^{2}$ seems to indicate that group A, B and C respectively, represents approximately 5, 11 and 64 pct. of the total population.

Traditionally, Chinese researchers have considered the system as consisting of two separate parts, an urban and a rural system. In this sense it can be linked to the so-called "hukou"-system - a population registration system where people are classified according to their geographical location. The A and B group is for people with city-hukou while the C-group is for people with rural-hukou. However, the individual hukou-status may change in connection with job changes. For instance, if a student with rural hukou moves to a city university he/she will receive a temporary city-hukou which may become permanent if this person gets a job in the city after graduation - but there are also many instances where people with rural hukou is actually working in the city industry without a hukou change. As we shall see, this mix up between job function and hukou-status often leaves weak groups of the population uncovered by the health care system.

\footnotetext{
2 According to Zhou Tianyong from Central Party University the number of A group members is approximately 70,000,000 (see Control the Personal Inflation of Civil Servants in China News 2005 http://www.chinanews.com.cn/news/2005/2005-06-12/26/585502.shtml (in Chinese).

According to the Annual Statistic Report 2005 from the Chinese Ministry of Labor and Social Security, the number of actually covered B-group members is 137,830,000. Finally, according to the 5th Nation Population Census by the National Bureau of Statistic of China, the number of (theoretically covered) C-group members is 807.39 million, i.e. the total size of the rural population.
} 
We emphasize the difference between A and B-group for several reasons: First, each of the three groups are actually regulated by a different ministry; China National Labour Union and the Ministry of Organization are responsible for the A-group, The Ministry of Labour and Social Security for the B-group, and Ministry of Health for the C-group. Second, on top of the difference in job function (public sector employees versus industry employees) there is a huge difference in their actual health benefits. Third, the actual relative size of the A group implies that they cannot be ignored as an independent group. However, insisting on treating A and B groups as independent (for the reasons mentioned) implies that many of the official data sources are difficult to fit into our framework and we shall mention specifically whenever this is the case.

For group A, all health care expenses are basically fully covered according to the 1988 regulation. However, the government has announced that there will be a gradual change of the conditions of the A-group towards a system more like that of the B-group, but up to now they have managed to maintain their "old" privileges (see also Section 2.1. below). ${ }^{3}$

For group B, which is under the "urban comprehensive medical care scheme", the system is more complicated. Basically, the system is designed as an employer-based insurance scheme $^{4}$ consisting of both an individual account and social pooling where it is intended that the individual pays $2 \%$ of the gross income ${ }^{5}$ to his/her personal account and that the enterprise pays in total $6 \%$ of the individuals income of which $30 \%$ is allocated to the individual account and $70 \%$ is allocated to the social pooling 6 . However, in effect the

3 Source: Opinion about Medical Care Subsidy of Civil Servants, Ministry of Labour and Social Security and Ministry of Finance, Office of State Council, May 20, 2000.

4 As argued in Dong (2006) this scheme is inspired by the Singaporean medical savings accounts model, which was implemented in Singapore in 1984.

5 In fact, typically individuals do not have to contribute to the individual account if their wage is below $60 \%$ of the local average wage and they only have to pay a maximum of $2 \%$ of 3 times the local average wage in case their income is above this amount. Both the average wage and the actual upper and lower thresholds vary among provinces and may be used as a means to control health care expenses.

6 These contribution rates may vary between regions according to the general economic situation. 
implementation of this scheme varies a lot between wealthy costal provinces and the rest of the country as well as between enterprises with different types of ownership. For instance, typically unskilled labour in privately owned enterprises are not covered by this type of scheme even though they are under the same regulation - this happens without local government sanctions although the policy seems to be changing on this issue. ${ }^{7}$

For group $\mathrm{C}$ there is no universal coverage, but there are various local initiatives trying to establish voluntary insurance schemes especially in the rich costal provinces. The main problem being that people are typically too poor to join these schemes and among those who actually join there is a large element of adverse selection as discussed in Wang et al. (2006). Usually the funds involved are very small and therefore these schemes have a limited effect. Moreover, around 100 million farm workers (with a growth rate of about 5 million per year according to Xinhua News 2005)8 actually work in the city industry and consequently should be enrolled in the scheme for the B-group, but in reality these workers are left uncovered.

The main structure of the general institutional setting is shown in figure Table 2.1 below. In short, there are three layers of government: central government, provincial government and city government. The central government is responsible for the general system design and for formulating policy and reform programs. The central government does not perform any direct reallocation of tax revenues, but there is some element of vertical transfers of funds to provinces in need of extra resources for their health care programs. The size of these funds is based on a bargaining procedure between the central

\footnotetext{
7 Cf. e.g. Announcement about Further Expansion of the Basic Medical Insurance Coverage, Wuxi City Labor and Social Security Bureau, Wuxi Labor and Social Security Net, March 9, 2002

http://www.wxlss.gov.cn/html/2002-03/2339.htm

See also Announcement about Further Expansion of the Basic Medical Insurance Coverage, Chongqing City Labor and Social Security Bureau, Health Chongqing Net, July 12, 2003

http://www.jkcq.com/zcfg/ybzq/200611/765.html.

(both in Chinese)

${ }^{8}$ http://www.cott.org.cn/newsdetail.cfm?iCntno=4140 (in Chinese)
} 
government and the provinces. The provincial governments collect their own tax revenues and administer the health care plans. They further share the responsibility with the city government for providing the services. However, it is quite normal in provinces with very heterogeneous conditions to arrange the social pooling at a city level.

Table 2.1.1. Overall institution arrangement

\begin{tabular}{|c|l|}
\hline Institutional level & \multicolumn{1}{|c|}{ Responsibilities } \\
\hline Central & $\begin{array}{l}\mid \\
\text {----Political and legal framemork } \\
\text {----Punding local government according to the } \\
\text { negotiation }\end{array}$ \\
\hline Provincial & $\begin{array}{l}\text {----Administration of social plan and individual } \\
\text { account } \\
\text {----Provision of services }\end{array}$ \\
\hline City & $\begin{array}{l}\text {----Administration of social plan and individual } \\
\text { account }\end{array}$ \\
& ----Provision of services \\
\hline * Typically provincial and city government share administration responsibility \\
according to the local economic development
\end{tabular}

\subsection{Financing the Health Care System}

Loosely speaking, the costs of running the Chinese health care system are financed by three main parties; the government, enterprises and individuals. The costs of government concern all levels of government, which are mainly covered by taxation but also by various sorts of user fees. Lately, however, the government has been in search of new sources of income, for instance, the public welfare lottery also contributes to health care financing. Moreover, local governments in rural areas typically make use of various types of fees when financing their health care initiatives. In China tax revenues primarily comes from income tax, turnover tax and sales tax on enterprises. Enterprises include both state owned, collectively owned ${ }^{9}$ and private enterprises. Immediately after the reform, mainly state owned enterprises paid their share of the basic medical care scheme (for the B-group)

9 Collectively owned enterprises are mainly found in the rural areas for historic reasons. 
but lately the government seems to emphasize active participation also of the private enterprises..$^{10}$ Finally, in the current Chinese health care system individual payments play a huge role. Although, the individual contribution to the social scheme is rather limited there is a huge additional out-of-pocket expense for the individuals since the social schemes are inadequate to cover all necessary expenses.

The total expenses of the current health care system as well as the allocation between government, social funds and personal expenses, is shown in Table 2.1.1. below.

Table 2.1.1. Total Health Care Expenditure in China.

\begin{tabular}{|c|c|c|c|c|c|c|c|}
\hline & 1980 & 1990 & 1995 & 2000 & 2002 & 2003 & 2004 \\
\hline Total Health Expenditure(100 million 1980 yuan) & 143.2 & 354.7 & 584.7 & 1226.6 & 1550.1 & 1741.8 & 1932.6 \\
\hline Total Health Expenditure(100 million yuan) current prices & 143.2 & 747.4 & 2155.1 & 4586.6 & 5790.0 & 6584.1 & 7590.3 \\
\hline Total health expenditure in \% of GDP & 3.17 & 4.03 & 3.69 & 5.13 & 5.51 & 5.62 & 5.55 \\
\hline $\begin{array}{l}\text { Government Health Expenditure in } \% \text { of total health } \\
\text { expenditure* }\end{array}$ & 36.2 & 25.1 & 18.0 & 15.5 & 15.7 & 17.0 & 17.1 \\
\hline Social Health Expenditure in $\%$ of total health expenditure ${ }^{* *}$ & 42.6 & 39.2 & 35.6 & 25.5 & 26.6 & 27.2 & 29.3 \\
\hline $\begin{array}{l}\text { Personal Health Expenditure in \% of total health } \\
\text { expenditure*** }\end{array}$ & 21.2 & 35.7 & 46.4 & 59.0 & 57.7 & 55.8 & 53.6 \\
\hline Per Capita Health Expenditure & 14.51 & 65.4 & 177.9 & 361.9 & 450.7 & 509.5 & 583.9 \\
\hline Per Capita Health Expenditure of Rural to Urban & & 1:4.1 & $1: 3.6$ & $1: 4.0$ & $1: 3.8$ & $1: 4.0$ & $1: 4.2$ \\
\hline \multicolumn{8}{|c|}{$\begin{array}{l}\text { * Government expenses include administration costs, health expenditures for government employees (civil servants in } \\
\text { the A-group) and the costs of providing health care corresponding to the budgets. } \\
\text { ** Social health expenditure includes coverage of personnel from public institutions (included in the A-group) as well } \\
\text { as group B and C. It also includes government budget imbalances and private insurance. } \\
\text { *** Personal health expenditure is individual out-of pocket expenses. }\end{array}$} \\
\hline
\end{tabular}

Source: Chinese Ministry of Health.

10 Cf. e.g. Announcement about Expansion of Social Insurance Coverage in 2004, Tianjing City Labor and Social Security Bureau, Tianjing Policy News March 312004.

(http://www.tjzb.org/system/2004/08/09/000044206.shtml) 
Total expenditure has increased considerably during the last two decades (with a factor 13 in fixed prices) which may be seen as a consequence of the health care reform itself as we shall discuss in Section 2.3.2 below (see also Blumenthal and Hsiao 2005). Expenses in percentage of GDP have remained relatively stable due to China's high growth rates. Moreover, there is a substantial difference between per capita expenses in rural and urban districts with urban expenses being four times higher than rural expenses - a ratio that has been relatively constant.

As a result of the reform the relative size of government health expenditure as well as the social health expenditure (which includes expenses of state owned enterprises) has decreased significantly. The direct government expenditure dropped from $36.2 \%$ in 1980 to $17.1 \%$ in 2004 while the social health expenditure dropped from $42.6 \%$ in 1980 to $29.3 \%$ in 2004. Meanwhile the private out-of-pocket part has drastically increased from $21.2 \%$ in 1980 to $53.6 \%$ in 2004 . On top of this, individual contributions to the social health expenditure have been introduced.

As indicated in Table 2.1.1 above, expenses of the A-group is divided according to whether it concerns civil servants or personnel of public institutions. For the civil servants health care expenses are registered under total government expenses, which primarily are covered by taxation. For personnel of the public institutions, the health care expenses are partly covered by the institutions themselves and are consequently registered under social health expenditure.

A detailed picture for the B-group is presented in Table 2.1.2 below. The number of people included in this scheme has been steadily increasing since the first experiments in the early 90ies until 2006 where a total of 157.3 million people are covered (with three times as many working as retired members). As mentioned earlier, the scheme consists of both an 
individual account (with an income corresponding to $3.8 \%$ of the total liability wage ${ }^{11}$ ) and a social plan (with an income corresponding to $4.2 \%$ of the total liability wage) but the actual burden is $2 \%$ for the individual and $6 \%$ for the enterprise. Both the individual account and the social plans are administered by the provincial government. As shown in Table 2.1.2, the income is larger than actual expenses concerning both the individual account and the social plans hence creating a positive accumulation. However, the data in Table 2.1.2 are aggregate data and expenses for the social plans may differ significantly between regions. In particular, one might expect to find positive accumulation in rich costal regions whereas it is not unusual to find negative accumulation in poorer regions.

Table 2.1.2. New urban comprehensive medical care scheme (B-group) $)^{12}$

\begin{tabular}{|c|l|l|l|l|l|l|l|l|l|l|}
\hline Year & $\begin{array}{l}\text { Working } \\
\text { people } \\
\text { (thousand) }\end{array}$ & $\begin{array}{l}\text { Retired } \\
\text { people } \\
\text { (thousand) }\end{array}$ & $\begin{array}{l}\text { Gross } \\
\text { income } \\
\text { of } \\
\text { individual } \\
\text { account } \\
\text { (million } \\
\text { Yuan) }\end{array}$ & $\begin{array}{l}\text { Gross } \\
\text { expenses } \\
\text { of } \\
\text { individual } \\
\text { account } \\
\text { (million } \\
\text { Yuan) }\end{array}$ & $\begin{array}{l}\text { Gross } \\
\text { income } \\
\text { of } \\
\text { society } \\
\text { plans } \\
\text { (million } \\
\text { Yuan) }\end{array}$ & $\begin{array}{l}\text { Gross } \\
\text { expenses } \\
\text { of } \\
\text { society } \\
\text { plans } \\
\text { (million } \\
\text { Yuan) }\end{array}$ & $\begin{array}{l}\text { Gross } \\
\text { income } \\
\text { (million } \\
\text { Yuan) }\end{array}$ & $\begin{array}{l}\text { Gross } \\
\text { expenses } \\
\text { (million } \\
\text { Yuan) }\end{array}$ & $\begin{array}{l}\text { Accumulation } \\
\text { in } \\
\text { society plans } \\
\text { (million } \\
\text { Yuan) }\end{array}$ & $\begin{array}{l}\text { Accumulation } \\
\text { in individual } \\
\text { account } \\
\text { (million } \\
\text { Yuan) }\end{array}$ \\
\hline 2006 & 115800 & 41520 & 70600 & 56000 & 104100 & 71700 & 174700 & 127700 & 107700 & 67500 \\
\hline 2005 & 100220 & 37610 & 58500 & 46400 & 82000 & 61500 & 140500 & 107900 & 75000 & 52800 \\
\hline 2004 & 90450 & 33590 & 51800 & 39800 & 62300 & 46400 & 114100 & 86200 & 55300 & 40500 \\
\hline 2003 & 79720 & 29270 & & & & & 89000 & 60780 & 37900 & 29100 \\
\hline 2002 & 69260 & 24740 & & & & & 60780 & 40940 & & \\
\hline 2001 & 54710 & 18150 & & & & & 38400 & 24400 & & \\
\hline
\end{tabular}

Source: annual statistic reports 2001-2006 from the Chinese Ministry of Labor and Social Security.

Concerning the C-group there is no universal coverage, but a series of local experiments under the "new rural cooperative medical care scheme". In 2005 there was a total of 678 experiments covering 176 million (22\%) of the rural population with a total income of 10.95 billion Yuan and a total expense of 6.18 billion Yuan. Of the total income, central government pays $10.24 \%$, local government pays $47.44 \%$ and communities (social

\footnotetext{
11 See footnote 5 .

12 In principle, these data may include part of the A-group because officially some A-group members are regulated by the new urban medical care scheme but no official information is available.
} 
network) as well as individuals pay $42.3 \%$. It seems that a large part of the central government expenditure is covered by income from the welfare lottery - until September 2005 it contributed 300 million out of a total central government expenditure of 540 million. Since the scheme is rather new the financing role of the central vs. the local government is still not clear and the central government is not committed to any formal arrangement with the provincial governments.

Although we have data for total expenses covered for the C-group there is no indication of burden sharing and furthermore, additional out-of-pocket expenses are not registered. Consequently, it is very difficult to obtain a general picture of the actual burden sharing between farmers, communities and local government. However, in specific regions more detailed information is available as in the case of the Shandong province ${ }^{13}$. Here the provincial government designed the subsidy scheme according to the village government's financial situation: for the five most prosperous areas (Jinan, Zibo, Dongyin, Weihai, Yantai) there is a provincial government subsidy of 8 Yuan per person per year, this subsidy is 24 Yuan for the six poorest areas and 12 Yuan for those in between. Since the total subsidy is 30 Yuan per person per year the village government covers the residual. Finally, the farmers themselves pay 10 Yuan per person per year to the village committees (social pooling at a community level). This scheme covers 40.63 million farmers $(66.98 \%)$ with a total provincial government subsidy of 360 million Yuan. Hence, contrary to the B-group, where social pooling takes place at a city or provincial level, social pooling for C-group is limited to take place at a village level.

Summing up, we are now able to produce an estimate of the burden sharing between the government, enterprises and individuals at a national level. Considering the burden we have data for both total health expenses and income for the social schemes. Since income of social schemes represent the actual expenses for individuals and enterprises we shall

\footnotetext{
13 Bureau of Health of Shandong province - 2006 data.
} 
use these amounts along with direct out-of-pocket expenses and expenses for the government. In this way we obtain the allocation in Table 2.1.3 using 2004 data:

Table 2.1.3. Burden sharing.

\begin{tabular}{|c|c|c|c|}
\hline & & 2004 & $\%$ \\
\hline \multirow{4}{*}{ Individuals } & out-of-pocket & 406.84 billion & \multirow{4}{*}{56} \\
\hline & $\begin{array}{l}\text { contribution to } \\
\text { social scheme of } \\
\text { B-group }\end{array}$ & 28.53 billion & \\
\hline & $\begin{array}{l}\text { contribution to } \\
\text { social scheme of } \\
\text { C-group }\end{array}$ & 4.63 billion* & \\
\hline & private insurance & 0.026 billion & \\
\hline Enterprises**** & $\begin{array}{l}\text { contribution to } \\
\text { social scheme of } \\
\text { B-group }\end{array}$ & 85.58 billion & 11 \\
\hline \multirow[t]{2}{*}{ The government } & total expenditure & 129.79 billion & \multirow[t]{2}{*}{33} \\
\hline & residual** & 131.54 billion & \\
\hline \multicolumn{4}{|c|}{$\begin{array}{l}\text { * } 2005 \text { data which is only one available } \\
\text { **the residual is the gap between adjusted total health expenditure of } 787 \text { billion (adjusting for the } \\
\text { difference between income and expenses of the urban scheme) and the inflow in total of } 656.36 \text {, which } \\
\text { is the sum of the income of social schemes as well as the actual expenditure of individual and } \\
\text { government. It covers extra investment to health institute and health expenditure for the employees in } \\
\text { public institutes. } \\
\text { ***Due to the fact that some members of the A-group may be included in the data of Table } 2.1 .2 \text { the } \\
\text { share of the enterprises may be overestimated (while the government is underestimated). }\end{array}$} \\
\hline
\end{tabular}

Table 2.1.3 shows that the health care burden of the enterprises is rather modest compared to the individual burden. In a broader perspective, though, there has been arguments stating that the total social burden of the enterprises, which includes pension and unemployment insurance, is too high (around 30\%), see e.g. Dongqiang and Lin (2004) and Ying (2004).

\subsection{Health care benefits}

Considering the B-group, the general principle seems to be that outpatient treatments (according to an official catalogue) are covered by the individual account and inpatient treatments (according to an official catalogue) are covered up to a certain limit by the 
social insurance plan. The actual details concerning the coverage as well as the list of approved treatments and drugs vary among provinces. In order to control the actual expenses it is common that the scheme includes some upper and lower threshold determined by the local government, outside of which the individual is left to pay out-of-pocket. Moreover, the list of approved treatments and drugs may of course be used to control the total expenses of the system.

It is worth noticing that rights are generally restricted to a particular province. Therefore, the individuals face a substantial transition cost since they can not use neither their individual account nor the social insurance across provinces. Consequently, in some regions with a high degree of migrate labor many of the workers only receive part of their benefits. For instance, in the Shenzhen city area, floating labor only joins the social pooling part of the scheme and therefore all outpatient visits are out-of-pocket expenses for this group.

In some of the early experiments the so-called Liang Jiang type of scheme was used. Here there is no difference between inpatient and outpatient treatments but a specified payment channel defining when expenses (above a certain lower threshold) are covered by the individual account, social account and out-of-pocket: first the individual account covers expenses and if this is insufficient the individual will pay out-of-pocket up to a maximum of $5 \%$ of the average wage, then the social plans will reimburse a gradually decreasing percentage of the remaining amount. Originally this scheme was intended to limit the costs of health care by limiting the element of social pooling, but was criticized for introducing too heavy a burden on the individual. Therefore, today most provinces have changed to the system described above.

Looking at the benefit side of the system, the A-group is basically fully covered. In particular, employees of public sector institutions are entitled to hospital bed expenses, medical inspection expense, drugs expenses, cost of treatments, operation fees, expenses from recovery services, first aid expenses, organ transplant expenses, etc. Note that, 
because there is a difference between the way that the health expenses are financed between civil servants and personnel of other public institutions, there may, in practice, be differences in the coverage between these groups, but in principle they are entitled to the same benefits.

As mentioned in Section 2.1 above, the conditions of the A-group are gradually changing and the Beijing area has been among the first to implement those changes. According to “The suggestion about implementation of medical care subsidy to the officials" from 2003, public servants who have been involved in the basic medical care system (including the retired and people who no longer work in the government after the government institution reform, but are still in the public servant personnel system) enjoy the benefits of the B-group and are entitled to additional subsidies, which cover expenses beyond the maximum limitation of the services included in the basic medical care drug and treatment catalogue, i.e., expenses paid by individual, which are below the deduction line and expenses of privilege treatment for high ranking officials ${ }^{14}$. Due to the subsidy, the level of compensation, in effects, equals that of free medical care ${ }^{15}$.

For the C-group there are no uniform conditions. In some regions there is basically no coverage and in others, like in the case of Jiang Shan, where individuals carry the major part of the burden (i.e. 30 Yuan per year out of a total on 52 Yuan), there is some element of coverage. In particular, farmers receive $10 \%$ coverage of outpatient visits to town

\footnotetext{
${ }^{14}$ In the Beijing area the public fiscal budget is only around 5\% of total salary last year according to official documents but obviously cannot cover the full expenses. It seems that no reliable data on true expenses are available.

15 In particular, inpatient expenses beyond maximum limitation, above 50 thousand per year are covered with $95 \%$ compensation. Expenses below 50 thousand per year are covered with $90 \%$ compensation. Individual burden of inpatient expenses (including individual account expenditure) are covered with 95\% for retired officers and officers at the rank of Chief of Bureau and above, and with 90\% otherwise. Outpatient expenses (including individual account expenditure) are covered with at least $90 \%$ compensation if the expenses exceed 1300 per year.
} 
hospitals (treating only less serious cases) without limits. Moreover, they receive inpatient coverage for expenses above 500 Yuan with an increasing percentage of coverage in fixed ranges ${ }^{16}$.

\subsection{Health Care Providers}

In China, government owned city hospitals form the backbone of urban health service delivery. These hospitals are ranked at three levels according to medical criteria and each level again contains three classes. To some extent this ranking matches the three layer governmental structure presented in figure 2.2. That is, top hospitals are typically administered by the Ministry of Health and thereby financed directly by the central government, while level 2 and 3 hospitals are administered by the provincial government and so forth. Table 2.3.1 below shows the total number of hospitals (not just public hospitals) according to the three level ranking. There are a relatively small number of hospitals at top level while more than half are outside the ranking system.

\footnotetext{
$1620 \%$ in the range $(500,1000]$ Yuan, 35\% in the range $(1000,2000]$ Yuan, $40 \%$ in the range $(2000,5000]$ Yuan, $50 \%$ in the range $(5000,10000]$ Yuan, $60 \%$ in the range $(10000,20000]$ Yuan and finally $70 \%$ in range 20000+ with total maximum benefit level of 20000 Yuan. In case the individual chooses a higher level hospital these percentages decrease. The full details of the plan are available at www.cncms.org.cn
} 
Table 2.3.1: The total number of hospitals according to the three level ranking

\begin{tabular}{|l|c|c|c|c|c|c|}
\hline & Sum & $\begin{array}{l}\text { General } \\
\text { Hospital }\end{array}$ & $\begin{array}{l}\text { TCM } \\
\text { Hospital }\end{array}$ & $\begin{array}{l}\text { TCM-WM } \\
\text { Hospital }\end{array}$ & $\begin{array}{l}\text { Minority } \\
\text { Hospital }\end{array}$ & $\begin{array}{l}\text { Specialized } \\
\text { Hospital }\end{array}$ \\
\hline Sum & 18703 & 12982 & 2620 & 194 & 195 & 2682 \\
\hline First Level & 946 & 633 & 152 & 15 & 2 & 144 \\
\hline $1^{\text {st }}$ Class & 594 & 388 & 103 & 11 & 1 & 91 \\
\hline $2^{\text {nd }}$ Class & 314 & 225 & 46 & 4 & 1 & 38 \\
\hline $3^{\text {rd }}$ Class & 38 & 20 & 3 & & & 15 \\
\hline Second Level & 5156 & 3557 & 1145 & 36 & 42 & 374 \\
\hline $1^{\text {st }}$ Class & 2744 & 1838 & 628 & 23 & 18 & 179 \\
\hline $2^{\text {nd }}$ Class & 2277 & 1626 & 438 & 12 & 19 & 181 \\
\hline $3^{\text {rd }}$ Class & 135 & 93 & 21 & 1 & 5 & 14 \\
\hline Third Level & 2714 & 2371 & 105 & 21 & 13 & 199 \\
\hline $1^{\text {st }}$ Class & 2042 & 1843 & 62 & 12 & 7 & 115 \\
\hline $2^{\text {nd }}$ Class & 509 & 418 & 24 & 6 & 5 & 55 \\
\hline $3^{\text {rd }}$ Class & 163 & 110 & 19 & 3 & 1 & 29 \\
\hline Others & 9887 & 6421 & 1218 & 122 & 138 & 1965 \\
\hline
\end{tabular}

Source: Chinese Ministry of Health

At lower levels, like town or village, people are typically referred to a local community hospital or a medical care center. Table 2.3.2 shows the different types of providers along with the total number of visits in rural areas. Even though the number of medical institutions seems quite high these institutions are typically rather small and perform only a very limited range of treatments. In terms of capacity, the number of beds per 1000 persons in hospitals and health centers is much higher in urban areas (3.56) than in rural areas (1.43). 
Table 2.3.2: Health Care Providers in Rural Area

\begin{tabular}{|l|l|r|c|}
\hline & & No. of providers & No. of visits \\
\hline \multirow{3}{*}{ County } & General hospitals & 2009 & \\
\cline { 2 - 4 } & Maternal and child care service center & 1526 & \\
\cline { 2 - 4 } & Sanitation and anti-epidemic station & 1586 & \\
\hline \multirow{2}{*}{ Town } & Community medical care center & 40907 & 59 million \\
\hline Village & Medical care centre & 583209 & 97 million \\
\hline
\end{tabular}

Source: Chinese Ministry of Health

For historical reasons many large state owned enterprises still operate their own hospital. The number of such hospitals is included in Table 2.3.1. In fact, due the historical development, ownership of hospitals and other types of medical institutions is not easily identifiable since many combined forms coexist. Table 2.3.3 below records the number of institutions according to ownership type.

Table 2.3.3: Number of institutions according to ownership

\begin{tabular}{|l|l|l|l|l|l|}
\hline & $\begin{array}{l}\text { State } \\
\text { owned }\end{array}$ & $\begin{array}{l}\text { Collectively } \\
\text { owned }\end{array}$ & $\begin{array}{l}\text { Joint } \\
\text { operation }\end{array}$ & Private & Other \\
\hline Total & $\begin{array}{l}93398 \\
(30.96 \%)\end{array}$ & $\begin{array}{l}44469 \\
(14.74 \%)\end{array}$ & $\begin{array}{l}8691 \\
(2.88 \%)\end{array}$ & $\begin{array}{l}143183 \\
(47.47 \%)\end{array}$ & $\begin{array}{l}11896 \\
(3.94 \%)\end{array}$ \\
\hline Hospital health & 13975 & 1508 & 133 & 2027 & 1060 \\
\hline $\begin{array}{l}\text { Community } \\
\text { centre }\end{array}$ & 46128 & 7572 & 1214 & 2131 \\
\hline $\begin{array}{l}\text { Health centre (urban, } \\
\text { township) }\end{array}$ & 25939 & 15121 & 34 & 271 & 329 \\
\hline Outpatient department & 2209 & 997 & 59 & 2043 & 588 \\
\hline Clinic & 31028 & 22191 & 893 & 139671 & 7778 \\
\hline First-aid station & 131 & 5 & 0 & 0 & 5 \\
\hline MCH centre & 2988 & 28 & 0 & 0 & 5 \\
\hline
\end{tabular}

Source: Chinese Ministry of Health

There is no system of General Practitioners (GP's), but each individual chooses directly among appointed service providers. In urban areas patients typically go directly to a hospital outpatient department and this department performs the function of the GP. In 
rural areas patients may also go to medical care centers. There is a possibility to be transferred within the system (both horizontally and vertically) in accordance to the needs of the patient, though in case of vertical transfers this means that the patient will receive a reduced coverage, see Section 2.2.

To indicate differences in the type of treatment that is received in urban versus rural areas one might consider the general education level on hospital versus township health care centers as in Table 2.3.4 below. It is striking that only 3.8\% of the personnel at hospitals are in fact physicians (with university master level and above) while the vast majority act as doctors but only have an education at BA level. Also, in the rural area health centers there are no professionally trained physicians.

Table 2.3.4: Percentage of health care personnel by educational level in 2002

\begin{tabular}{|c|c|c|}
\hline By Educational Level & Hospital & $\begin{array}{l}\text { Township } \\
\text { Health Center }\end{array}$ \\
\hline Doctor's Degree & 0.8 & 0.0 \\
\hline Master's Degree & 3.0 & 0.0 \\
\hline University & 38.8 & 2.9 \\
\hline Junior College & 33.2 & 24.9 \\
\hline $\begin{array}{c}\text { Secondary Technical } \\
\text { School }\end{array}$ & 20.7 & 56.5 \\
\hline High School and Below & 3.6 & 15.8 \\
\hline
\end{tabular}

Source: Chinese Ministry of Health.

Considering the workload of physicians it appears that top hospitals produce more treatments and inpatient days than lower ranking hospitals (see Table 2.3.5 below). At first glance this seems counter intuitive since one might expect to find more complicated (and thereby more resource consuming) treatments at top hospital level. However, one explanation could be that patients have the option to go to a top hospital and do that in cases of standard treatments, which they can afford. Therefore, top hospitals perform a lot of minor surgery and other types of standard treatment. 
Table 2.3.5:

\begin{tabular}{|c|c|c|c|c|}
\hline \multicolumn{5}{|c|}{ workload for physicians } \\
\hline \multirow{2}{*}{$\begin{array}{l}\text { Hospitals } \\
\text { financed at: }\end{array}$} & \multicolumn{2}{|c|}{$\begin{array}{l}\text { treatment per physician per } \\
\text { day }\end{array}$} & \multicolumn{2}{|c|}{$\begin{array}{l}\text { inpatient days for per } \\
\text { physician per day }\end{array}$} \\
\hline & 2005 & 2004 & 2005 & 2004 \\
\hline ministry level & 7.8 & 7.3 & 2.3 & 2.2 \\
\hline province level & 6.6 & 6.2 & 2.1 & 2.0 \\
\hline big city level* & 5.7 & 5.1 & 1.9 & 1.7 \\
\hline small city level & 5.0 & 4.8 & 1.4 & 1.3 \\
\hline county level & 4.3 & 4.0 & 1.4 & 1.3 \\
\hline
\end{tabular}

* provincially administered city

Source: Chinese Ministry of Health

Compared with many western systems it is furthermore striking that the every Chinese hospital have an integrated pharmacy taking care of the provision of drugs, although in the big cities, more and more independent pharmacies appear. The obvious moral hazard problems in this connection will be discussed in Section 2.3.2 below.

Treatment and drug charges are highly regulated. For treatments on the approved list as well as all prescription drugs prices are regulated either by a fixed fee schedule or by a guided price determined by the government. In case of a guided price the government determines some upper limit for the markup (10 - 15\% for drugs and 5\% for high-technology procedures). Around $40 \%$ of the drug market is regulated. Non-prescription drugs are only market priced if not on the approved list. Market priced drugs account for the remaining $60 \%$ of the total drug market. Treatments not on the approved list are market priced like for instance, births. ${ }^{17}$

\subsubsection{Financing the service delivery}

17 Cf. China Drug Control Law (from 2002) and China Price Control Law (from 1997). 
Hospital income basically originates from three sources: government subsidies (primarily for covering fixed costs such as buildings, equipment and wages), patient out-of-pocket expenses and individual account payment and reimbursements from the social insurance plans.

Concerning the reimbursements from the social insurance scheme, many hospitals went from a fee-for-service based reimbursement scheme to a prepayment scheme similar to a monthly budget after reforms in 199718. Based on what the hospital received in a given month the previous year they are pre-paid $90 \%$ of this amount in the current year with the promise of an additional 10\% if the hospital maintain its quality level (according to the yearly quality review). Hospitals are further compensated ex post for unexpected cost factors according to an overall judgment. The specific details of the contracts are somewhat complicated, see Yip and Eggleston (2004).

The prepaid scheme can be compared to the situation before 1997 where the reimbursements were based on fee-for-service. In order to compensate the hospitals for the reduced state subsidies following the economic reforms, hospitals were allowed to charge fees that exceeded average costs on certain types of high-technology tests and procedures as well as prescription drugs. As to be expected this led to serious cost inflation since it gave hospitals the incentive to overprescribe drugs and high-technology procedures. Basically, this is the reason for the present day structure of the insurance system and the provider payment reforms (the Hainan reforms) initiated in 1997. Yip and Eggleston (2004) demonstrate that the prepayment scheme apparently has had a positive effect slowing the rate of growth of expenditures, especially for expensive drugs and high-technology procedures.

To obtain a general overview of income and expenditure data for hospitals consider Table 2.3.6 below. It appears that on average medical treatment and drugs are equally important

18 Typically modelled over the Hainan experiment. 
income generators for all types of hospitals, but typically (on average) profits are negative for medical treatments while they are strictly positive on drug sales (again independent of the type of hospital). Of course these numbers may conceal substantial differences between individual hospitals ${ }^{19}$ but the overall picture seems to be in line with the fact that the government regulates treatment prices below actual costs and that the hospitals are forced to compensate through profits made on prescription drugs.

\footnotetext{
19 To get an impression from an individual hospital we may consider the following case from Shaoxing city in Zhejiang province: Hospital income per year is 222,457,000 Yuan, which consists of medical income of $54,520,000$ Yuan, drug income of 99,107,000 Yuan and some (unspecified) residual income of 68,830,000 Yuan. Compared to the average distribution (in Table 2.3.6 above) we see that drug income is particularly high constituting half of the total income. Meanwhile, hospital expenditure per year is 205,667,000 Yuan consisting of medical expenditure of 119,555,000 Yuan and drug expenditure of 84,488,000 Yuan, which are in accordance with the average picture in Table 2.3.6 above. Looking at average medical expense per outpatient (Yuan) the total amount of 135.80 Yuan is shared as 81.70 Yuan for drug, 20.30 Yuan for examination and 12.30 Yuan for diagnosis. Average medical expense per inpatient is 7610.90 Yuan which is shared as 3176.70 Yuan for drug, 406.30 Yuan for examination, 1633.60 Yuan for treatment and 550.40 Yuan for surgery.
} 
Table 2.3.6: Income and expenditure of hospitals of health sectors in 2005

\begin{tabular}{|c|c|c|c|c|c|c|}
\hline & $\begin{array}{l}\text { General } \\
\text { hospital }\end{array}$ & $\begin{array}{l}\text { Hospital } \\
\text { of MOH }\end{array}$ & $\begin{array}{l}\text { Province } \\
\text { Hospital }\end{array}$ & $\begin{array}{l}\text { Hospitals of } \\
\text { City } \\
\text { prefecture }\end{array}$ & $\begin{array}{l}\text { Hospital of } \\
\text { City } \\
\text { County level }\end{array}$ & $\begin{array}{l}\text { County } \\
\text { Hospital }\end{array}$ \\
\hline $\begin{array}{l}\text { Income per Hospital } \\
\text { (million yuan) }\end{array}$ & 55.756 & 798.927 & 319.949 & 95.653 & 31.510 & 20.443 \\
\hline $\begin{array}{c}\text { of which: } \\
\text { Business Income }\end{array}$ & 51.749 & 758.919 & 300.942 & 87.660 & 29.486 & 18.786 \\
\hline Medical Income & 26.857 & 399.482 & 159.093 & 45.465 & 15.006 & 9.636 \\
\hline Drug Income & 23.836 & 340.573 & 136.635 & 40.580 & 13.767 & 8.705 \\
\hline Other income & 1.056 & 18.864 & 5.215 & 1.615 & 0.713 & 0.443 \\
\hline $\begin{array}{l}\text { Expenditure per hospital } \\
\text { (million yuan) }\end{array}$ & 53.457 & 775.454 & 304.785 & 91.438 & 30.462 & 19.643 \\
\hline $\begin{array}{c}\text { of which: } \\
\text { Business expenditure }\end{array}$ & 51.749 & 752.122 & 295.388 & 88.460 & 29.710 & 18.839 \\
\hline Treatment expenditure & 30.200 & 453.379 & 172.631 & 51.818 & 17.193 & 10.829 \\
\hline Drug expenditure & 20.961 & 292.368 & 119.395 & 35.664 & 12.158 & 7.776 \\
\hline Other expenditure & 0.588 & 6.375 & 3.363 & 0.978 & 0.358 & 0.234 \\
\hline $\begin{array}{l}\text { Average medical expense } \\
\text { per outpatient (yuan) }\end{array}$ & 126.9 & 247.1 & 192.5 & 130.7 & 105.2 & 84.2 \\
\hline of which: for drugs (yuan) & 66.0 & 136.7 & 102.0 & 69.3 & 53.5 & 41.0 \\
\hline $\begin{array}{l}\text { Average medical expense } \\
\text { per inpatient (yuan) }\end{array}$ & 4661.5 & 12650.9 & 9871.2 & 5452.4 & 3380.9 & 2266.5 \\
\hline of which: for drugs (yuan) & 2045.6 & 5089.9 & 4186.1 & 2374.6 & 1544.6 & 1057.8 \\
\hline $\begin{array}{c}\text { for examination } \\
\text { \& treatment }\end{array}$ & 1230.6 & 3460.6 & 2602.5 & 1501.2 & 864.5 & 550.8 \\
\hline
\end{tabular}

Source: Chinese Ministry of Health (www.moh.gov.cn)

\subsubsection{Provider incentives}

To understand hospitals incentives it is necessary to understand the conditions under which they are actually working. To some extent, the public hospitals are independent units, but still receiving government subsidies primarily to cover part of their fixed costs (such as buildings and capital). Since the hospitals are not fully sponsored by the government they gain some freedom to pursue other than public interests. Meanwhile, the 
hospitals are not privately owned profit maximizing entities so they actually end up being primarily pursuing staff interests; that is, not caring about cost minimization while still required to obtain a certain level of profitability.

There are many indicators pointing towards the management of hospitals pursuing staff interests. For instance, various sorts of inefficiencies are often debated, such as a decreasing workload of doctors and low utilization rates of capital (beds and equipment) etc. (Wang, 2004) Moreover, it is commonly known that there is a widespread tendency of over-treating patients using too many (and unnecessary) drugs, high-technology tests and procedures.

For example, in the Shandong province, a retired provincial government official (that is, A-group member), Wang Jie, stayed in a top ranking hospital for 22 days being treated for pneumonia. In the end he died and total charges reached the striking figure of 20,000 Yuan. ${ }^{20}$ Interestingly, it turned out that he did not use all prescribed drugs since family members attained more than 100 unopened drug packages from hospital after his death. Medical records show that he was prescribed 171 different types of drugs and as the bill is paid per day the maximum charge for a single day reached 5576 Yuan. ${ }^{21}$

Also, it is well known that patients usually pay so-called "red-bag money" to doctors treating their case (to be seen as very big tip meant to ensure good service) and doctors furthermore obtain commission from their drug sales. In fact, more than $90 \%$ of marketed priced drugs are sold with commission implying that the doctors have incentive to choose

20 For comparison, average yearly income is 16614 Yuan per capita in the urban area of Shandong province in 2005. Source: Statistic Yearbook of Shandong 2006, Shandong Statistic Information Net http://www.stats-sd.gov.cn/tjsj/nj2006/NJ04/HTML/0415.htm

${ }^{21}$ A family member of Wang said, "it is hard for a person without medical knowledge, to tell which drug should be used. But it is obvious that doctors treat a given sickness with multiple drugs with the same curative effect." Source: http://www.southen.com 
maximum commission drugs among those with the same curative effects. For example, a given tumor drug sold at a hospital pharmacy at price 2000 Yuan, includes actual expense for the hospital of only 100 Yuan and doctors commission of 500 Yuan - leaving both a good commission to the doctor and a good profit for the hospital.

Both "red-bag money" and commission are examples of hospital management accepting that doctors are quite powerful in making their own production decisions pursuing their own interests. It could also be viewed as part of a motivating payment scheme chosen by the hospital, but in connection with low degrees of efficiency it seems more likely to be the result of the former.

Together, inefficiency and employee power creates high production costs, which again pushes treatment and drug prices upwards. The highly limited state subsidies are further fueling this effect. Further, in competing for states subsidies as well as for general demand, hospitals further increase production costs since typically more subsidies and patients go to hospitals with a high level of service and technological equipment. The final result being that public hospital prices exceed private hospital prices. To finance the purchase of high-technology medical devises and buildings, hospitals typically have huge debts to state banks. ${ }^{22}$ Since the banks are also state owned the hospitals are reluctant to pay back their debts because in the end the government cannot justify closing down hospitals.

Considering the relation between service provider and the social plans, the change from a fee-for-service scheme to a pre-payment scheme obviously has changed the incentives of the provider. Under fee-for-service the hospitals lack incentive to reduce overall production costs because the reimbursement is based directly on their activity level. Meanwhile, a pre-paid 90\%-budget induces some element of cost-consciousness by

\footnotetext{
22 As an example cf. e.g. Huge debts of local public hospital in Dongbei area, Health News November 13, 2007 http://health.sohu.com/20071113/n253230097.shtml (in Chinese).
} 
introducing supply side cost sharing although in principle the $90 \%$-budget limits the residual saving to a maximum of $10 \%$. The positive effect on overall costs is also partly neutralized by the fact that hospitals face a ratchet effect in their efforts to save on costs, see Yip and Eggleston (2004).

In case of the drug market, the fact that hospitals and pharmacies are integrated units strongly limits the effect of government price regulation. In general prices on drugs are considered to be too high due to the situation mentioned above. However, when the government tries to lower drug prices of market priced drugs, the room for pharmaceutical companies to give discounts to hospital pharmacies and doctors will be smaller. As a result of this, doctors tend to substitute to another type of drug and the pharmaceutical companies will respond by changing the drug (either changing name, or dosage, or package) so that it will appear as a new type of medicine which may be market priced again (until it ends up at the regulated list). This type of product change is difficult to disclose for the government price bureau. In fact, from 1998 to 2006 the government implements drugs price reduction 17 times without success. ${ }^{23}$ Average scope for price reduction increased from $15 \%$ to $40 \%$ and the loss for the pharmaceutical companies for each reduction amounts to billions of Yuan.

Not surprisingly, the regulation of the drug market has lead to a headed debate in China where the pharmaceutical industry complain about loss of profitability and argues for free market prices, but the public opinion seems to be that prices are still too high and need more government regulation.

\section{Main Problems}

23 Cf. The puzzle of 17 times No Effective Drug Price Deduction, Xinhua Net 2005.10.31 http://news.xinhuanet.com/fortune/2005-10/31/content_3707704.htm (in Chinese) 
Having been trough the main structure of the Chinese health care system it is clear that the system faces many acute problems and serious future challenges. Even though the system is constantly trying to adapt to population needs and improve its performance there is official recognition of fundamental problems like insufficient coverage and lack of expenditure control. ${ }^{24}$ The central government is aware of the necessity of increasing its investment in health care substantially; see e.g. Hsiao (2007). As we have seen above even official data seems to indicate rather serious problems, which further more tend to interact and create a complicated situation for the governing authorities.

To briefly sum up, the main problems concern:

Coverage: In effect the current system design excludes the poorest and most vulnerable groups, especially a large part of the rural population. However, the system seems to change towards an urban and a rural system (like now) but with global coverage including people outside the labour market - adding a new scheme to the B-scheme which includes children, unemployed etc. But there are no details about financing yet. ${ }^{25}$

Pooling level: Even when people are covered there may still be problems related to the actual pooling level. Typically the individual and social accounts are city or region specific. This means that if a given person is covered in one city or region and moving to another he/she does not have

\footnotetext{
24 Cf. Four Most Serious Problems of China Medical Care Insurance Reform, Xinhua Net July 162005. http://finance.sina.com.cn/money/insurance/bxsd/20050706/17251767967.shtml (in Chinese).

25 Cf. Policy Explanation from Ministry of Labor and Social Security: Establishment of Basic Medical Insurance System for All Urban Inhabitants, Xinhua Net July 25, 2007. http://news.xinhuanet.com/politics/2007-07/25/content_6429758.htm (in Chinese)
} 
the right to coverage in that city or region. Obviously this is a huge problem for the growing migrating labour force but in principle it concerns everyone.

Limited access: Looking at who actually receives the benefits in the system it turns out that there are huge inequalities. In reality many people in need of medical services are left without the possibility of receiving help even though they are covered by the official system. This is because it typically requires considerable additional out-of-pocket expenses to receive medical care. Often insurance premiums are low resulting in limited benefit coverage, in terms of low reimbursement rates (20-30\%) for both outpatient and inpatient services (see e.g. Hu 2004) and this creates highly limited access. Even official data indicates that there are serious problems. For example, the ratio between people who should receive a medical service but did not was 36.4\% (in 1993) and has risen to $48.9 \%$ in 2003. In particular for rural areas this ratio was $63.7 \%$ (in 1998) and has risen to $75.4 \%$ (in 2003) according to the third National Health Service Investigation by the Chinese Ministry of Health 2003.

Provider efficiency: Due to price regulation and lack of a well-functioning referral system, patients prefer going to top ranking hospitals producing long waiting lists while at the same time there is free capacity in lower ranking hospitals. This obviously gives a bad utilization of the available capacity of the system. Moreover, at all levels of government, investment seems to be focused on top-ranking hospitals only to make the problem worse.

Cost inflation: Because of price regulation combined with lack of public funding the hospitals are allowed to make a profit on certain high-technology treatments and drugs. Due to serious moral hazard problems hospitals have incentives to divert activity into profit giving areas creating substantial cost inflation. 
Credibility problem: People (especially in rural area) are typically distrustful of the local government insurance fund management and worried that their insurance premiums might be diverted to other uses. Moreover, the central government launches many different experiments in different regions and nobody knows which system they will finally adopt. Obviously this creates much confusion as to the functioning of the final system and consequently some reluctance and distrust to the current one.

The problems of coverage and pooling level are in many ways interrelated. One way of solving the coverage problem would be to organize the social pooling on a national level, which in effect leads to a national health care system. However, such a solution seems difficult to realize because of huge regional differences in China. For instance, in poorer regions the current system may not even be fully implemented and these regions will further typically lack the information systems necessary to make the health insurance plans operational. Therefore, in practice the system must consist of regional risk pooling. While it is relatively obvious that the individual accounts should follow people when they move between regions it is less obvious how the accounts connected with social pooling should be allocated and how the local authorities should cooperate on this issue. The credibility problem seems to increase these difficulties because people lack confidence in the current system, feel uncertain about future benefits, especially the ones who expect future migration among cities and are therefore reluctant to increase the coverage.

The many instances of provider inefficiency push cost inflation and thereby aggravate the problem of limited access simply because few people can afford treatment as this typically requires too large additional out-of-pocket expenses. It is somewhat ironic that price regulation ensuring cheap basic treatment, which was meant to promote access, seems to have had the direct opposite effect due to wrong provider incentives. 


\section{Conclusion and Future Challenges}

Looking at future trends, the Chinese health care system seems to face a substantial increase in demand. There are at least three main reasons for that.

Firstly, the present coverage is very limited - even the most optimistic estimate is that the current system covers less than one quarter of the total population (Liu 2004) and since the government intent to change the system from being based on job function to being based on citizenship in urban areas this change alone in the number of people covered is likely to increase future demand.

Secondly, the "one child policy" has at least two crucial effects, namely an aging population and a future inability of the family to take care of the elderly. Obviously an ageing population will demand more health care resources simply because elderly persons require more health care. Moreover, since the burden of the elderly will increase for the family household the younger members will no longer be able to take care of the elderly themselves. Therefore, they will be forced to outsource this function requiring the professional services of public and/or private nursing homes.

Finally, with the rapidly growing middle class and good economic conditions in general, demand for quantity as well as quality of health care is likely to increase drastically.

With the current problems of the Chinese health care system (e.g. lack of public funding and educated health care personnel) it is obvious that this demand increase can not be met directly by the public health care system. This leads to further substantial cost inflation and increased pressure on top ranking hospitals as well as increased pressure for the introduction of private providers.

Moreover, the supply side faces a dilemma: on the one hand, public health care resources are obviously insufficient and most public hospitals are in urgent need of investments; on 
the other hand, according to the current regulation, private capital is not allowed to invested in the public health care sector. ${ }^{26}$

Solutions to this dilemma are fiercely discussed in China at the present moment. Typically, public hospitals would like to lease buildings and equipment financed by private capital but the private investors on the other hand want to be involved more directly in the running and management of hospitals. ${ }^{27}$ Especially foreign investors have shown great interest for entering the Chinese health care market ( for example, according to the survey of Chinese hospitals Holdings Ltd, there are approximately 60 billion US dollars of funds in attention to China's medical market).

Facing the combination of the hospitals urgent need of increased funding and the substantial interest shown by private investors to enter the market given acceptable conditions, the Chinese government now seems ready for a process opening up for private capitalization. According of a former health minister the government intent to encourage foreign capital to enter various large city hospitals subject to a $70 \%$ limit of ownership but no official plan is announced yet.

\section{References}

Blumenthal, D. and W. Hsiao (2005), Privatization and its discontents - the evolving Chinese health care system, The New England Journal of Medicine, 352, 1165-1170.

26 Cf. Administration of state asset of state owned non-profit organizations, 2006.

27 For example, on October 27, 2007, at a convention concerning the financial situation of hospitals, a director of a local level II public hospital argued that leasing hospital buildings financed by private capital would greatly improve their situation. However, the president of Chinese hospitals Holdings Ltd. Jiang Tao responded: "We are not real estate investors; we would like to be involved in hospital management through acquisitions holding. It's not feasible to invest without private capitalization." 
Development Research Center of the State Council \& WHO (2005), Chinese Health Care system Reform, Research report.

Dong W. (2006), Can health care financing policy be emulated? The Singaporean medical savings account model and its Shanghai replica, Journal of Public Health, 28, 209-214.

Eggleston K., L. Ling, M. Qingyue, M. Lindelow and A. Waagstaff (2007), Health service delivery in China: A literature review, Health Economics, forthcoming.

Hu T-W, M. Ong, Z-H. Lin and E. Li (1999), The effects of economic reform on health insurance and financial burden for urban workers in China, Health Economics, 8, 309-321.

Hu T-W. (2004), Financing and organization of China's health care, Bulletin of the World Health Organization, 82.

Hsiao W. (1995), The Chinese health care system: lessons for other nations, Social Science and Medicine, 41, 1047-1055.

Hsiao W. (2007), The political economy of Chinese health reform, Health Economics, Policy and Law, 2, 241-249.

Liu, Y. (2004), China's public health care system: facing the challenges, Bulletin of the World Health Organization, 82, 532-538.

Qiu, Y. (2004), Opinion about urban sharing of enterprise of social insurance fee, Economists, 6 (in Chinese). 
Yip W. and K. Eggleston (2004), Addressing government and market failures with payment incentives: Hospital reimbursement reform in Hainan, China, Social Science and Medicine, 58, 267-277.

Yip W. and W. Hsiao (1997), Medical savings accounts: Lessons from China, Health Affairs, November-December issue, 244-251.

Wang H., L Zhang, W. Yip and W. Hsiao (2006), Adverse selection in a voluntary rural mutual health care health insurance scheme in China, Social Science E Medicine, 63, 1236-1245.

Wang, S. (2005), Crisis and challenge of China public health system, Comparative Studies,

Wei, D. and M. Lin (2004), The development and complete of Chinese social security system, Chinese Finance Information, 19 (in Chinese). 